\title{
Comparative study of the radiosensitising and cell cycle effects of vinflunine and vinorelbine, in vitro Cindy Simoens*1, Filip Lardon1 ${ }^{1}$, Bea Pauwels ${ }^{1}$, Christel MJ De Pooter ${ }^{2}$, Hilde AJ Lambrechts ${ }^{1}$, Greet GO Pattyn ${ }^{1}$, Fabienne Breillout ${ }^{3}$ and Jan B Vermorken ${ }^{1}$
}

Address: ${ }^{1}$ Laboratory of Cancer Research and Clinical Oncology, Department of Medical Oncology, University of Antwerp (UA/UZA), Wilrijk (Antwerp), Belgium, ${ }^{2}$ Department of Radiotherapy, St. Augustinus Hospital, Wilrijk (Antwerp), Belgium and ${ }^{3}$ Institut de Recherche Pierre Fabre, Centre de développement Oncologie, Boulogne Cedex, France

Email: Cindy Simoens* - cindy.simoens@ua.ac.be; Filip Lardon - filip.lardon@ua.ac.be; Bea Pauwels - bea.pauwels@ua.ac.be; Christel MJ De Pooter - christel.depooter@gvagroup.be; Hilde AJ Lambrechts - hilde.lambrechts@ua.ac.be; Greet GO Pattyn - greet.pattyn@ua.ac.be;

Fabienne Breillout - fabienne.breillout@pierre-fabre.com; Jan B Vermorken - erna.ledure@uza.be

* Corresponding author

Published: 29 February 2008

BMC Cancer 2008, 8:65 doi:10.1 186/147/-2407-8-65

This article is available from: http://www.biomedcentral.com/147I-2407/8/65

(c) 2008 Simoens et al; licensee BioMed Central Ltd.

This is an Open Access article distributed under the terms of the Creative Commons Attribution License (http://creativecommons.org/licenses/by/2.0), which permits unrestricted use, distribution, and reproduction in any medium, provided the original work is properly cited.
Received: 17 April 2007

Accepted: 29 February 2008

\begin{abstract}
Background: Vinca alkaloids are an important class of anticancer agents and semisynthetic vinca alkaloids are developed to improve the therapeutic index of this class of drugs. In the present study, a direct comparison was made between vinflunine and vinorelbine regarding their radiosensitising and cell cycle effects.
\end{abstract}

Methods: Four human tumour cell lines were tested under identical experimental conditions, using equitoxic concentrations of vinflunine and vinorelbine.

Results: Vinflunine and vinorelbine induced a comparable radiosensitising effect ( $p$-value never below $0.0 \mathrm{I}$ ) when cells were incubated for $24 \mathrm{~h}$ immediately prior to radiation. Regarding the cell cycle effects, a statistically significant concentration-dependent G2/M block was seen after $24 \mathrm{~h}$ incubation with vinorelbine in all tested cell lines. Similar results, with small cell line-related differences, were observed with vinflunine.

Conclusion: The radiosensitising effects of both semisynthetic vinca alkaloids were comparable (not statistically different) and nearly always cell line-specific and concentration-dependent. The cell cycle effects could be related to the observed radiosensitising effects. Considering the more favourable toxicity profile of vinflunine, this agent might be more promising than vinorelbine for chemoradiation studies in the clinic.

\section{Background}

Vinca alkaloids are an important class of antitumour agents used in chemotherapy, either as single agents or in combination regimens. Semisynthetic vinca alkaloids, such as vinorelbine (VRL) and most recently vinflunine
(VFL), have been developed to improve the therapeutic index [1]. Like the other vinca alkaloids, VRL and VFL exert their antitumour effect by binding to tubulin, the major component of microtubules in mitotic spindles. They diminish microtubule dynamics and assembly, 
which ultimately results in cell cycle arrest at the metaphase/anaphase transition [2,3]. However, they also differ from the naturally occurring vinca alkaloids in chemical structure, microtubule selectivity, and toxicity. In that respect, the capacity of VRL to bind preferentially to mitotic rather than axonal microtubules may imply that occurrence of neurotoxicity is less likely with VRL than with vinblastine or vincristine, and may predict a wider therapeutic window for VRL [4]. VFL also displays some differences in the interaction with microtubules, compared to all the other vinca alkaloids, which may lead to different effects on cell cycle progression and cell death [5-7]. In the clinic, both VRL and VFL have demonstrated activity i.e. in the treatment of non-small cell lung (NSCLC), metastatic breast (MBC) and bladder cancer [813].

\section{Vinflunine versus vinorelbine}

Although VFL has a structure close to that of VRL, the selective introduction of the two fluorine atoms seemed to influence the drugs characteristics:

- VFL's potency with respect to both inhibition of cell proliferation and mitotic block is lower than that of VRL [6]. VFL exhibits a relatively low in vitro cytotoxic potency, but has shown superior in vivo activity against a series of murine and human tumour experimental models [14-16]. These data may suggest a wider spectrum of activity for VFL and studies are underway to evaluate if this enhanced efficacy can be translated into an improved spectrum of clinical activity for VFL [16].

- VFL also has a 3-16 fold lower overall binding affinity for tubulin than VRL [17]. The lower affinity of VFL may explain, at least in part, the high concentrations of the drug needed to block mitosis and cell proliferation [18]. These findings do not explain the relatively high therapeutic efficacy of VFL. However, the therapeutic index of a drug with a relatively weak potency may be broader than that of an extremely potent drug [6]. In this context, the NMR study of Fabre et al. [19] revealed the presence of specific binding sites and showed a different affinity of VFL and VRL to the tubulin dimer at physiological temperatures. This could account for their different toxicity, and not necessary implies a different mechanism of action between these compounds, and is in agreement with in vivo and in vitro observations.

- The peak intracellular drug concentrations at the mitotic IC50-value are highest for VFL $(4.2 \pm 0.2 \mu \mathrm{M}$ vs $1.3 \pm 0.1$ $\mu \mathrm{M}$ for VRL). This suggests that intracellular binding reservoir(s) may be partially responsible for VFL's high efficacy, by providing a reservoir for excess drug and enabling its gradual release [6]. VFL also induces significantly smaller spirals (tubulin aggregates) than VRL and demon- strates shorter relaxation times compared with VRL [17]. This lower overall binding affinity for tubulin, together with the smaller spirals, the shorter relaxation times and the gradual release, suggest that VFL may demonstrate reduced neurotoxicity relative to VRL [17].

- Finally, VFL seems to be a far less potent inducer of drug resistance relative to VRL $[15,20]$.

\section{Chemoradiation}

There is increasing interest in the combined use of chemotherapy and radiotherapy in the clinic for various tumour types, such as NSCLC, head and neck, oesophageal and cervical cancer [21-25]. Improved outcomes in patients are most likely a result of increased systemic and local tumour control, and from a direct interaction between cytotoxic agents and radiation. This latter aspect should preferably be investigated in vitro first in order to optimise the clinical application of the combination.

The in vitro ability of VRL to potentiate radiation was already evaluated in several human NSCLC cell lines (NCI-H460, A549 \& PC9) [26,27], SCLC cells (SBC-3) [28], and head \& neck carcinoma cell lines [29]. The results were cell line-dependent, and showed an additive effect or a dose-dependent potentiation of radiation. In a previous study, we investigated the in vitro ability of VFL to potentiate radiation in 4 different human tumour cell lines (bladder, head \& neck, breast and lung tumour cell lines). A dose-dependent radiosensitising effect was shown after $24 \mathrm{~h}$ treatment with VFL immediately prior to radiation, in all cell lines [30].

In the current study, the radiosensitising and cell cycle effects of VFL and VRL are compared, using the same set of 4 human tumour cell lines and identical experimental conditions for both drugs. In this manner, the radiosensitising effect of vinflunine can be placed in a more identifiable context.

\section{Methods \\ Cell lines}

Four different human tumour cell lines were used in this study: ECV304, an epidermoid bladder cancer cell line; CAL-27, a squamous cell carcinoma cell line of the tongue; MCF-7, a breast cancer cell line; and H292, a mucoepidermoid NSCLC cell line. ECV304 cells were cultured in Medium 199 (Invitrogen, Merelbeke, Belgium); CAL-27 and MCF-7 cells in DMEM medium (Invitrogen), supplemented with $2 \mathrm{mM}$ glutamine (Invitrogen); and H292 cells in RPMI-1640 medium (Invitrogen), supplemented with $2 \mathrm{mM}$ glutamine and $1 \mathrm{mM}$ sodium pyruvate (Invitrogen). All media were completed with 10\% foetal calf serum (Invitrogen), no antibiotics were added. Cul- 
tures were maintained in exponential growth at $37^{\circ} \mathrm{C}$ in a humidified 5\% $\mathrm{CO}_{2}$ atmosphere.

\section{Vinorelbine and vinflunine}

VRL and VFL were kindly provided by the 'Institut de Recherche Pierre Fabre', Boulogne, France. For VRL, each vial consisted of $1 \mathrm{ml}$ containing $10 \mathrm{mg}$ free base in solution (i.e. $10 \mathrm{mg} / \mathrm{ml}$ ); for VFL, each vial consisted of $2 \mathrm{ml}$ containing $50 \mathrm{mg}$ free base in solution (i.e. $25 \mathrm{mg} / \mathrm{ml}$ ). Both VRL and VFL were diluted in sterile normal saline $(0.9 \% \mathrm{NaCl})$ to make a stock solution of $3 \mu \mathrm{M}$ and $30 \mu \mathrm{M}$ respectively, and were stored at $4{ }^{\circ} \mathrm{C}$ (no longer than 2 months). Before use, the stock solutions were further diluted in $0.9 \% \mathrm{NaCl}$ to the desired concentration.

\section{Cytotoxicity and chemoradiation experiments}

Cells were harvested from exponential phase cultures (at $50-75 \%$ confluence) by trypsinisation, counted and plated at optimal seeding densities in 48-well plates to assure exponential growth during the experiments. Seeding densities were about 1200, 2000, $2200 \& 2800$ cells/ well in the cytotoxicity experiments and about 250, 100, 150 \& 120 cells/well in the chemoradiation experiments, for ECV304, CAL-27, H292, and MCF-7, respectively. After a $24 \mathrm{~h}$ recovery period, cells were treated during 24 $\mathrm{h}$ with VRL or VFL. For determining the cytotoxic effect, a concentration range of both compounds was tested (0-80 nM VRL/0-400 nM VFL, dissolved in 0.9\% NaCl). After the incubation period, cells were washed with drug free medium and cell survival was determined by the sulforhodamine B (SRB) assay 4 days after the start of treatment. In the chemoradiation experiments, cells were treated with specified concentrations of VRL or VFL (see Table 1) and this was immediately followed by radiation (Cobalt-60 $\gamma$ rays, 0-8 Gy, room temperature). Experiments were started with low VFL concentrations and these were increased until a clear radiosensitising effect was observed. For VRL, about equitoxic concentrations were applied. After radiation, cells were washed with drug free medium and incubated at $37^{\circ} \mathrm{C}$ for 7 or 8 days (about 6 doubling times). Cell survival was determined again by the SRB assay, a reliable assay in these circumstances, as described previously [31].

$0.9 \% \mathrm{NaCl}$ alone was added to control cells. Each concentration was tested 6 times within the same experiment and all experiments were performed at least 3 times. The SRB assay was performed according to the method of Skehan et al. and Papazisis et al. [32,33], with minor modifications [30].

\section{Cell cycle experiments}

Exponential growing cells (at 50-75\% confluence) were trypsinised, counted and plated in 6-well plates. In order to assure exponential growth during the experiments, seeding densities were about 75000 cells/well for the first set of experiments, and about 50000 cells/well for the cell cycle kinetics experiments. After at least a $24 \mathrm{~h}$ recovery period, two different cell cycle experiments were performed as follows:

- Firstly, the effect of VRL or VFL on the cell cycle was investigated. For these experiments, cells were incubated for $24 \mathrm{~h}$ with specified concentrations of VRL or VFL (0$50 \mathrm{nM} / 0-400 \mathrm{nM}$ ) and flow cytometry was performed immediately after incubation.

- Secondly, the cell cycle was investigated over time (cell cycle kinetics). For these experiments, not only different incubation times were investigated $(4-48 \mathrm{~h})$, but also different time points after a $24 \mathrm{~h}$ incubation $(3-72 \mathrm{~h})$. Therefore cells were treated during $24 \mathrm{~h}$ with VRL or VFL and cell cycle analysis was performed $0,3,24,48$ or $72 \mathrm{~h}$ after drug wash out (indicated as $24+0,24+3,24+24$, $24+48,24+72$, respectively). The concentrations used for this second set of experiments were identical to those resulting in a clear G2/M block in the first set of experiments with VFL, and their equitoxic VRL concentrations, i.e. $30 \mathrm{nM}$ VRL/150 nM VFL for ECV304 and H292, $15 \mathrm{nM}$ VRL/150 nM VFL for MCF-7 and $15 \mathrm{nM}$ VRL/100 nM VFL for CAL-27 cells.

Cell cycle analysis was performed by flow cytometry, after DNA staining, according to the Vindelov method [34], as described previously [30].

\section{Data analysis and statistics}

\section{Cytotoxicity and chemoradiation experiments}

The survival rates were calculated by: mean optical density (OD) of treated cells/mean OD of untreated cells $\times 100 \%$. The survival curves after treatment with VRL or VFL alone were fitted according to the sigmoid inhibition model: $\exp ($ survival $)=1-\left(\mathrm{C}^{\gamma} / \mathrm{C}^{\gamma}+\mathrm{IC} 50^{\gamma}\right)$. The radiation dose-survival curves were fitted according to the linear-quadratic model: survival $=\exp \left(-\alpha \mathrm{D}-\beta \mathrm{D}^{2}\right)$, using WinNonlin (Pharsight, Palo Alto, CA, USA). The radiation dose-survival curves were corrected for the cytotoxic effect of VRL or VFL alone. From these dose-survival curves, the following parameters were calculated: the IC50, i.e. the concentration VRL or VFL causing 50\% growth inhibition; the ID50, i.e. the radiation dose causing 50\% growth inhibition; and the mean inactivation dose (MID), which was calculated by numerical integration of the linear-quadratic curve [35]. A two-sample t-test was used to investigate significant differences at the level of ID50 and MID values, between control cells (only irradiated) and cells treated with the combination of chemo- and radiotherapy. The same statistical analysis was also performed to compare equitoxic concentrations of VRL with VFL in the chemoradiation experiments. Statistical significance was 
defined at the level of $\mathrm{p}<0.01$. The results are expressed as mean \pm standard error. Radiosensitisation was represented by the dose enhancement factor (DEF): ID50 (without VRL or VFL)/ID50 (with VRL or VFL). Possible synergism was determined by calculation of the combination index (CI) by the Chou and Talalay equation [36], using CalcuSyn (Biosoft, Cambridge, UK), which can be used for chemoradiation combinations [37]. The CI quantifies drug interaction in terms of additive effect $(\mathrm{CI}=1)$, synergism $(\mathrm{CI}<1)$, or antagonism $(\mathrm{CI}>1)$. The $\mathrm{CI}$ takes into account both the potency (IC50 or $\mathrm{D}_{\mathrm{m}}$ ) and the shape of the dose-survival curve ( $\mathrm{m}$ value, signifying the sigmoidicity of the dose-effect curve). The general equation for the classic isobologram is given by:

$$
\mathrm{CI}=(\mathrm{D})_{1} /\left(\mathrm{D}_{\mathrm{x}}\right)_{1}+(\mathrm{D})_{2} /\left(\mathrm{D}_{\mathrm{x}}\right)_{2}
$$

where $\left(D_{x}\right)_{1}$ and $\left(D_{x}\right)_{2}$ are the doses (or concentrations) for $\mathrm{D}_{1}$ (VRL or VFL) and $\mathrm{D}_{2}$ (radiation) alone, required to inhibit cell growth by $50 \%$, and $(D)_{1}$ and $(D)_{2}$ are the doses of VRL or VFL and radiation in combination that also inhibit cell growth by $50 \%$ (i.e., isoeffective as compared with the single treatments).

The $\left(D_{\mathrm{x}}\right)_{1}$ or $\left(\mathrm{D}_{\mathrm{x}}\right)_{2}$ (for VRL or VFL and radiation) are calculated by the formula:

$$
D_{x}=D_{m}\left[f_{a} /\left(1-f_{a}\right)\right]^{1 / m}
$$

Where $D_{m}$ is the dose required to produce absorbance readings 50\% lower than those of non-treated wells (IC50 or ID50), $\mathrm{f}_{\mathrm{a}}$ is the fraction affected and $\mathrm{m}$ is the slope of the median-effect plot. The CI values obtained from the classic (mutually exclusive) isobologram calculations were used. In short: $1.10>\mathrm{CI}>0.90,0.90>\mathrm{CI}>0.85$, $0.85>\mathrm{CI}>0.70$ and $0.70>\mathrm{CI}>0.30$ indicating additivity, slight synergism, moderate synergism and synergism, respectively.

\section{Cell cycle experiments}

Flow cytometric data were analysed using Cell Quest (Becton Dickinson). In our experiments, polyploid cell populations appeared after treatment with both VRL and VFL. Therefore, besides the normal cell cycle phases G1, S and $\mathrm{G} 2 / \mathrm{M} ; \mathrm{S}_{2}$ (second synthesis phase, without previous mitosis) and polyploid G2/M ((G2/M) ${ }_{2}$, cells in G2/M after $\mathrm{S}_{2}$ ), with a double DNA content compared to cells in normal G2/M, were explored.

A 2 sample t-test was used to investigate the significance of the differences between the percentages of cells in the different cell cycle phases after treatment with VRL or VFL versus the untreated cells, $24 \mathrm{~h}$ incubation, $24+0 \mathrm{~h}$, and $24+24 \mathrm{~h}$ schedule (see previous section for the explanation of the different treatment schedules), and to compare equitoxic concentrations of VRL with VFL. Statistical significance was defined at the level of $\mathrm{p}<0.05$. The results are expressed as mean \pm standard error.

\section{Results}

\section{Cytotoxicity experiments}

To investigate and compare the cytotoxic effect of VRL and VFL, IC50-values were calculated for both drugs. All tested cell lines were 5-8 times more sensitive to VRL than to VFL (data not shown). These results enabled us to use equitoxic concentrations of VRL and VFL to directly compare the radiosensitising and cell cycle effects of these two compounds.

\section{Chemoradiation experiments}

The radiation parameters of the 4 human tumour cell lines treated with radiation alone or with the combination of VRL and radiation are summarised in Table 1. The combination of VRL and radiation resulted in more cell kill compared to the control curves (irradiation only) in all 4 cell lines. In ECV304, radiosensitisation was already seen at concentrations around IC15 $(\mathrm{DEF}=1.49)$, resulting in slight synergism using CI calculations. For H292, concentrations around IC20 were required $(\mathrm{DEF}=1.36)$ to observe a moderate synergistic effect, and for CAL-27 cells, concentrations around IC45 $(\mathrm{DEF}=1.92)$ resulted in clear synergism. With higher VRL concentrations, an increase in radiosensitivity was observed in all these cell lines (higher DEFs, accompanied by a decrease of ID50 and MID values). In MCF-7 however, once a radiosensitising effect was established (from low concentrations on), the effect was not dose proportional with VRL. The resulting DEF $( \pm 1.5)$ was equal for every tested concentration (between IC20 and IC55), although CI calculation showed an increase from an additive effect to moderate synergism.

The radiation dose-survival curves of VFL have been presented earlier and indicated a radiosensitising effect in all tested cell lines [30]. The MID, ID50, DEF and CI-values for VFL are also summarised in Table 1 . The radiosensitising effect of VFL was most pronounced in ECV304 cells, already at concentrations around IC10 (moderate synergism). In MCF-7 and H292, radiosensitisation was seen at concentrations around the IC40 (synergism and moderate synergism, respectively), while rather toxic concentrations around IC70 were required in CAL-27 cells to induce a synergistic effect.

To compare the effects of both VFL and VRL on radiation, equitoxic concentrations of VRL were used. The data suggest that the radiosensitising effects of VFL and VRL are comparable, since statistical analysis - performed to compare equitoxic VRL concentrations with VFL - never reached statistical significant differences ( $p$-value never 
Table I: Radiation parameters of the four human tumour cell lines, for VRL and VFL; mean values \pm standard error.

\begin{tabular}{|c|c|c|c|c|c|c|c|c|}
\hline Cell line & Conc. (nM) & IC-value* & $N$ & Mean MID & Mean ID50 & Mean DEF & Mean Cl & \\
\hline & VRL & & & & & & & \\
\hline \multirow[t]{3}{*}{ ECV304 } & 0 & & 13 & $3,23 \pm 0,14$ & $2.71 \pm 0.15$ & & & \\
\hline & 4 & $\mathrm{ICI} 5$ & 8 & $2,45 \pm 0,24^{a}$ & $1.88 \pm 0.23^{a}$ & $1.49 \pm 0.13$ & $0.89 \pm 0.01$ & slight synergism \\
\hline & 6 & IC30 & 9 & $2,10 \pm 0,21^{a}$ & $1.56 \pm 0.16^{a}$ & $1,97 \pm 0,26$ & $0,77 \pm 0,0 \mathrm{I}$ & moderate synergism \\
\hline \multirow[t]{3}{*}{ CAL-27 } & 0 & & 9 & $3,23 \pm 0,12$ & $2.99 \pm 0.12$ & & & \\
\hline & 2,5 & IC45 & 9 & $2,22 \pm 0,20^{a}$ & $1.68 \pm 0.19 a$ & $1,92 \pm 0,24$ & $0,69 \pm 0,01$ & synergism \\
\hline & 3,5 & IC75 & 8 & $\mathrm{I}, 8 \mathrm{I} \pm 0,24^{\mathrm{a}}$ & $1.33 \pm 0.17 \mathrm{a}$ & $2,49 \pm 0,41$ & $0,51 \pm 0,01$ & synergism \\
\hline \multirow[t]{3}{*}{ MCF-7 } & 0 & & 19 & $3.26 \pm 0.12$ & $2.80 \pm 0.16$ & & & \\
\hline & 3 & IC20 & 17 & $2.66 \pm 0.17 \mathrm{a}$ & $2.00 \pm 0.15^{\mathrm{a}}$ & $1.48 \pm 0.05$ & $0.93 \pm 0,02$ & additivity \\
\hline & 4 & IC55 & 11 & $2.55 \pm 0.28^{a}$ & $1.94 \pm 0.2 \mathrm{I}^{\mathrm{a}}$ & $1.47 \pm 0.10$ & $0.78 \pm 0,04$ & moderate synergism \\
\hline \multirow[t]{4}{*}{$\mathrm{H} 292$} & 0 & & 16 & $3,69 \pm 0,10$ & $2.91 \pm 0.10$ & & & \\
\hline & 3 & $\mathrm{ICIO}$ & 15 & $3,18 \pm 0,18$ & $2.51 \pm 0.16$ & $1,19 \pm 0,06$ & $0,97 \pm 0,02$ & additivity \\
\hline & 4 & $\mathrm{IC} 20$ & 5 & $2,59 \pm 0,27^{a}$ & $2.00 \pm 0.22^{\mathrm{a}}$ & $1,36 \pm 0,06$ & $0,83 \pm 0,04$ & moderate synergism \\
\hline & VFL & & & & & & & \\
\hline \multirow[t]{3}{*}{ ECV304 } & 0 & & 5 & $3.18 \pm 0.25$ & $2.46 \pm 0.28$ & & & \\
\hline & 30 & $\mathrm{ICIO}$ & 5 & $2.12 \pm 0.26$ & $1.56 \pm 0.16$ & $1.57 \pm 0.11$ & $0.84 \pm 0.01$ & moderate synergism \\
\hline & 50 & $\mathrm{IC} 25$ & 5 & $1.66 \pm 0.08^{a}$ & $1.26 \pm 0.05^{a}$ & $1.93 \pm 0.14$ & $0.71 \pm 0.01$ & moderate synergism \\
\hline \multirow[t]{3}{*}{ CAL-27 } & 0 & & 5 & $3.24 \pm 0.13$ & $2.81 \pm 0.17$ & & & \\
\hline & 25 & IC40 & 4 & $2.48 \pm 0.23$ & $2.01 \pm 0.26$ & $1.41 \pm 0.09$ & $0.98 \pm 0.04$ & additivity \\
\hline & 30 & IC70 & 4 & $1.63 \pm 0.06^{a}$ & $1.22 \pm 0.05^{\mathrm{a}}$ & $2.29 \pm 0.23$ & $0.57 \pm 0.02$ & synergism \\
\hline \multirow[t]{3}{*}{ MCF-7 } & 0 & & 4 & $4.00 \pm 0.34$ & $3.18 \pm 0.26$ & & & \\
\hline & 30 & IC40 & 4 & $3.07 \pm 0.38$ & $2.29 \pm 0.29$ & $1.42 \pm 0.13$ & $0.77 \pm 0.01$ & moderate synergism \\
\hline & 40 & $1 \mathrm{C} 60$ & 4 & $1.93 \pm 0.16^{\mathrm{a}}$ & $1.48 \pm 0.14^{\mathrm{a}}$ & $2.24 \pm 0.08$ & $0.54 \pm 0.01$ & synergism \\
\hline \multirow[t]{3}{*}{$\mathrm{H} 292$} & 0 & & 4 & $5.16 \pm 0.36$ & $4.42 \pm 0.31$ & & & \\
\hline & 30 & $\mathrm{ICIO}$ & 4 & $4.55 \pm 0.64$ & $3.55 \pm 0.46$ & $1.29 \pm 0.14$ & $1.27 \pm 0.12$ & additivity \\
\hline & 40 & IC40 & 3 & $3.60 \pm 0.21^{a}$ & $3.03 \pm 0.20^{a}$ & $1.53 \pm 0.02$ & $0.77 \pm 0.03$ & moderate synergism \\
\hline
\end{tabular}

$N=$ number of experiments

MID = mean inactivation dose

ID50 = radiation dose causing $50 \%$ growth inhibition

$\mathrm{DEF}=$ Dose Enhancement Factor

$\mathrm{Cl}=$ Combination Index

${ }^{a} \mathrm{p}<0.01$ compared to control ( $0 \mathrm{nM}$ VFL)

$*$ IC-value represents the concentration of VRL or VFL causing a specific percentage of inhibition of cell growth
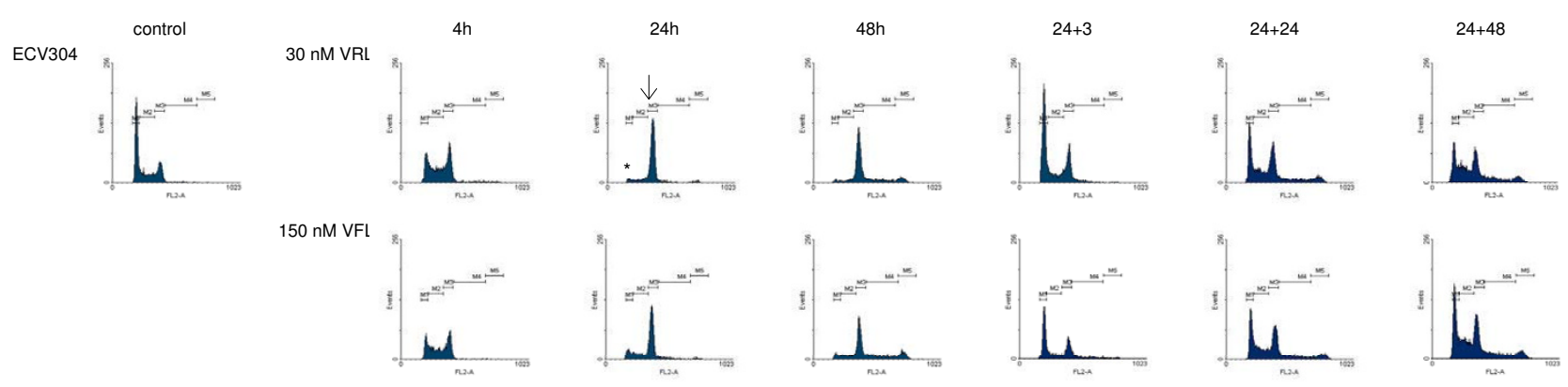

$\downarrow$ : indicates a statistically significant higher amount of G2/M phase cells after VRL treatment compared to VFL, which coincided with a lower percentage of cells in G1 $\left(^{*}\right)$.

\section{Figure I}

DNA histograms of vinorelbine and vinflunine in ECV304 cells. detailed legend: DNA histograms of ECV304 cells treated with equitoxic concentrations of vinorelbine or vinflunine during 4, 24 and 48 hours and 24 and $48 \mathrm{~h}$ after drug removal. FL-2A = DNA content. Events = number of fluorescent nuclei. 
below 0.01). However, cell line specific and concentration-dependent differences were noticed. A marked difference between the two drugs was observed in the MCF-7 cell line, where, contrary to VFL, the radiosensitising effect of VRL was found to be not concentration-dependent. However, this did not reach statistical significance (borderline) since the p-value was only 0.08 comparing $4 \mathrm{nM}$ VRL with $40 \mathrm{nM}$ VFL.

\section{Cell cycle experiments}

Figures 1, 2, 3, 4 show representative DNA-histograms of all tested cell lines after different time points of exposure to VRL or VFL, and at different time points after drug removal.

Cell cycle effects after $24 \mathrm{~h}$ treatment with vinorelbine or vinflunine Table 2 summarises the percentages of cells in the different phases of the cell cycle (G1, S \& G2/M) for all tested cell lines, treated with a low and a high VRL concentration, which approximates an equitoxic VFL concentration of 60 and $150 \mathrm{nM}$ (these VFL concentrations were selected because they showed a significant G2/M block in these cell lines in previous experiments). Immediately after 24 h treatment with VRL, a concentration-dependent G2/M block was observed in all cell lines (Figures 1, 2, 3, 4, Table 2). In ECV304, a statistically significant G2/M block was observed with $30 \mathrm{nM}$ VRL (high VRL concentration), which coincided with a significant decrease of cells in G1 and S phase. No clear cell cycle effect was observed with lower concentrations. In CAL-27, MCF-7 and H292, a statistically significant G2/M block was apparent with the low VRL concentrations, S phase cells were unchanged, but cells in G1 were decreased. The amount of cells arrested in G2/M increased with increasing concentration, although this effect was only moderately expressed in MCF-7 cells. As in ECV304, these higher VRL concentrations caused statistically significant changes in the amount of G1 and S phase cells. Similar results were observed with VFL [30].

By comparing the results of VRL with those of VFL, a statistically significant higher amount of G2/M phase cells could be observed in ECV304 cells with 30 nM VRL compared to that observed with the equitoxic $150 \mathrm{nM}$ VFL dose. The same trend was observed for both concentrations of VRL in H292 cells. Treatment with 15 and $40 \mathrm{nM}$ VRL resulted in a higher amount of arrested cells in the G2/M phase than with VFL, which coincides with a lower percentage of cells in G1 after VRL treatment compared to VFL. In CAL-27 and MCF-7 cells, no statistical differences were observed for the cell cycle effects of VRL versus VFL after 24 h treatment.

\section{Cell cycle kinetics}

Table 3 summarises the percentages of cells in the G2/M phase, after treatment with different incubation times with VRL or VFL ( $4-48$ h of continuous incubation). In all cell lines, a statistically significant increase in the percentage of cells in G2/M was already visible after $4 \mathrm{~h}$ incubation with VRL. A maximal G2/M block was reached after about $16 \mathrm{~h}$ incubation in all the tested cell lines. After this maximum was reached, the amount of arrested G2/M phase cells remained unchanged, or slightly decreased towards the $48 \mathrm{~h}$ incubation period. In CAL-27, however, a statistically significant decrease of G2/M blocked cells was observed with the $48 \mathrm{~h}$ incubation, accompanied by a strong statistically significant increase of cells in the polyploid population at that time (see below).

Table 4 summarises the percentages of cells in the G2/M phase of the cell cycle, different hours after drug removal. $3 \mathrm{~h}$ after removal of VRL, the percentage of cells in G2/M decreased significantly in all cell lines $(\mathrm{p}<0.05$ compared to $24+0$ ). This release of cells from G2/M coincided with
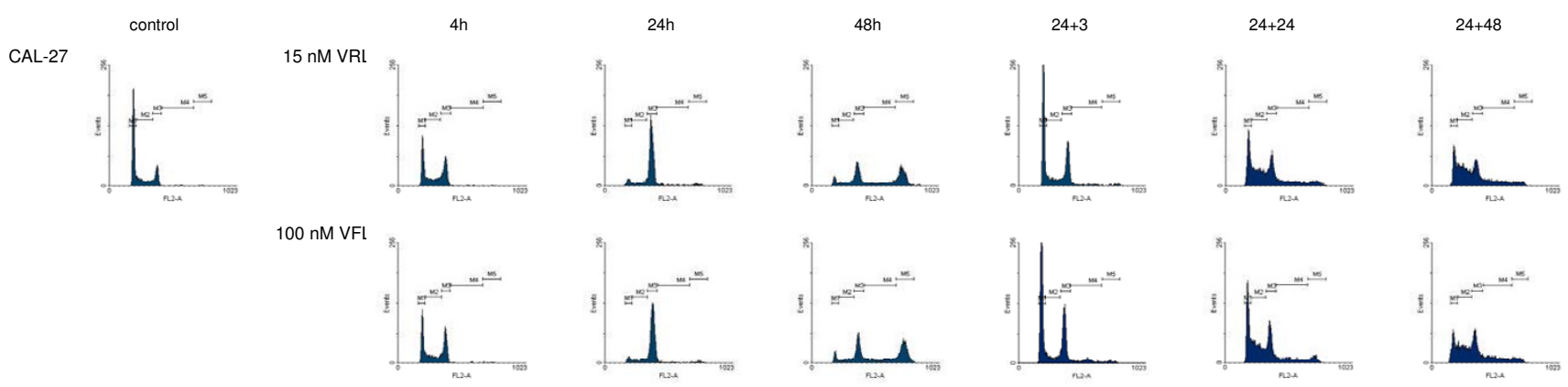

Figure 2

DNA histograms of vinorelbine and vinflunine in CAL-27 cells. detailed legend: DNA histograms of CAL-27 cells treated with equitoxic concentrations of vinorelbine or vinflunine during 4, 24 and 48 hours and 24 and 48 h after drug removal. FL-2A = DNA content. Events = number of fluorescent nuclei. 


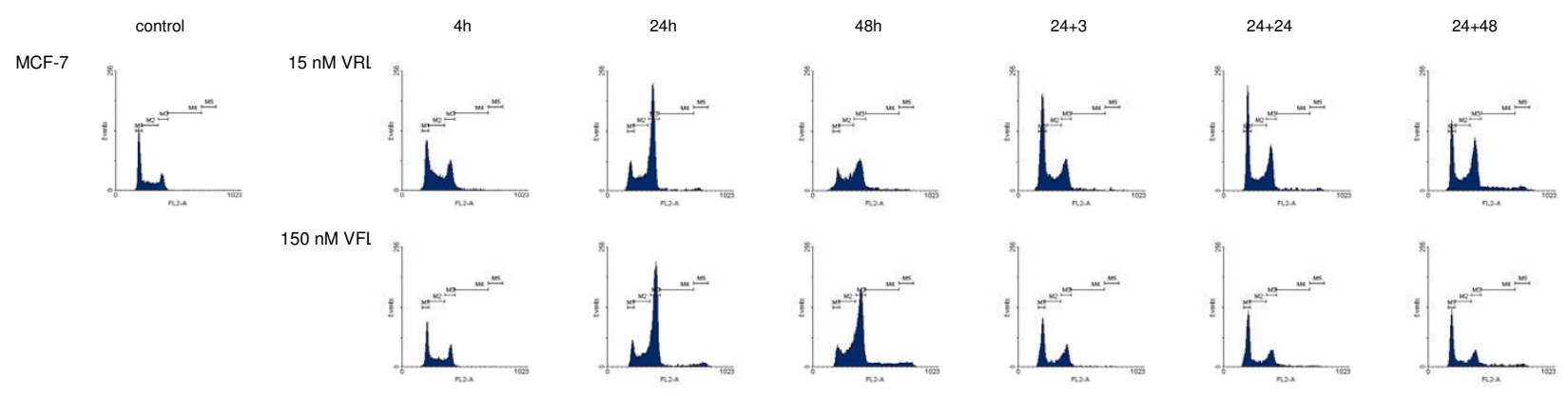

Figure 3

DNA histograms of vinorelbine and vinflunine in MCF-7 cells. detailed legend: DNA histograms of MCF-7 cells treated with equitoxic concentrations of vinorelbine or vinflunine during 4, 24 and 48 hours and 24 and $48 \mathrm{~h}$ after drug removal. FL-2A $=$ DNA content. Events $=$ number of fluorescent nuclei.

an increase in the number of cells in G1 (data not shown) and the polyploid cell cycle (Table 5), and suggested that the accumulated cells in $\mathrm{G} 2 / \mathrm{M}$ had re-entered the cell cycle with or without mitosis (normal or polyploid cell cycle). $24 \mathrm{~h}$ after VRL removal, a stable cell cycle was established again (no significant differences anymore between 24+24 and 24+72) in CAL-27 and MCF-7 cells. In ECV304, the cell cycle distribution had stabilised $48 \mathrm{~h}$ after drug removal and the amount of G2/M cells reached control levels again. In H292, it took $72 \mathrm{~h}$ or longer to regain a stable cell cycle distribution.

Similar cell cycle effects were observed using the same treatment schedules with VFL [30]. Only in ECV304, the $\mathrm{G} 2 / \mathrm{M}$ block after $24 \mathrm{~h}$ VRL incubation was more pronounced (as shown above), since the maximal G2/M arrest was maintained longer with this agent. Three hours after removal of VRL, the amount of cells in G2/M was therefore still significantly higher in this cell line compared to VFL. However, in MCF-7 cells, the amount of cells blocked in G2/M was statistically lower after VRL treatment (except for the $24 \mathrm{~h}$ timepoint) then after VFL treatment.

\section{Polyploid cell cycle}

Table 5 summarises the percentages of cells in the polyploid cell cycle $\left(\mathrm{S}_{2}\right.$ and $\left.(\mathrm{G} 2 / \mathrm{M})_{2}\right)$ after $24 \mathrm{~h}$ and $48 \mathrm{~h}$ of incubation with VRL or VFL, and after drug removal $(24+24 \& 24+48)$. The results obtained with VRL were similar to those obtained with VFL. After $24 \mathrm{~h}$ and even more pronounced after $48 \mathrm{~h}$ of continuous incubation, a polyploid cell population was clearly observed in CAL-27 and ECV304 (Figure 1 and 2), and to a lesser degree also in H292 and MCF-7 ( $\mathrm{p}<0.05$ compared to control). Only
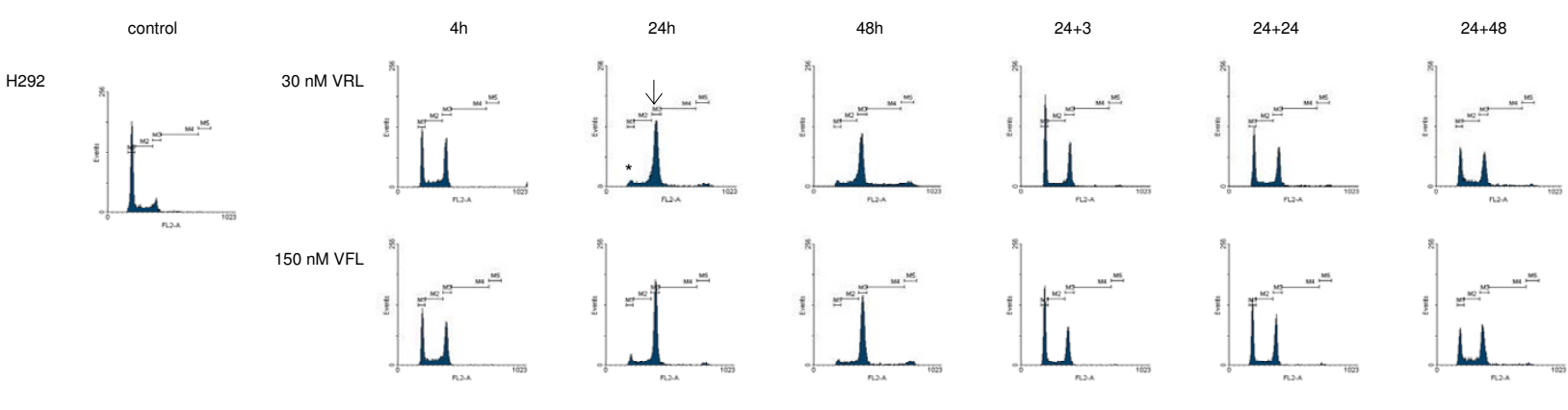

$\downarrow$ : indicates a statistically significant higher amount of G2/M phase cells after VRL treatment compared to VFL, which coincided with a lower percentage of cells in G1 (*).

\section{Figure 4}

DNA histograms of vinorelbine and vinflunine in $\mathbf{H 2 9 2}$ cells. detailed legend: DNA histograms of $\mathrm{H} 292$ cells treated with equitoxic concentrations of vinorelbine or vinflunine during 4, 24 and 48 hours and 24 and $48 \mathrm{~h}$ after drug removal. FL-2A = DNA content. Events = number of fluorescent nuclei. 
Table 2: Cell cycle distributions after $24 \mathrm{~h}$ incubation with equitoxic concentrations of VRL and VFL.

\begin{tabular}{|c|c|c|c|c|c|}
\hline Cell line & Contr & $60 \mathrm{nM}$ VFL & Equitoxic conc. VRL & 150 nM VFL & Equitoxic conc. VRL \\
\hline & $\%$ GI & & & & \\
\hline ECV304 & $39.1 \pm 1.9$ & $36.3 \pm 2.2$ & $(10 \mathrm{nM}) 38.6 \pm 2.8$ & $15.0 \pm 3.4^{\mathrm{a}}$ & $(30 n M) 10.1 \pm 1.6^{a}$ \\
\hline CAL-27 & $56.4 \pm 1.7$ & $19.0 \pm 1.0^{a}$ & $(10 \mathrm{nM}) 19.0 \pm 3.4^{\mathrm{a}}$ & $9.2 \pm 1.1^{a}$ & $(30 \mathrm{nM}) 8.1 \pm 1.5^{\mathrm{a}}$ \\
\hline MCF-7 & $50.3 \pm 1.5$ & $19.1 \pm 2.3^{a}$ & $(8 \mathrm{nM}) 18.0 \pm 1.7^{\mathrm{a}}$ & $11.3 \pm 3.1^{\mathrm{a}}$ & $(20 \mathrm{nM}) 10.9 \pm 1.8^{\mathrm{a}}$ \\
\hline \multirow[t]{2}{*}{$\mathrm{H} 292$} & $56.5 \pm 0.9$ & $39.3 \pm 2.4^{\mathrm{a}}$ & $(15 \mathrm{nM}) 25.6 \pm 3.0 \mathrm{a} *$ & $15.0 \pm 3.0^{\mathrm{a}}$ & $(40 \mathrm{nM}) 9.3 \pm 2.6^{\mathrm{a}}$ \\
\hline & $\% S$ & & & & \\
\hline ECV304 & $38.6 \pm 1.6$ & $44.1 \pm 2.9$ & $(10 \mathrm{nM}) 37.1 \pm 1.6$ & $26.4 \pm 3.2^{\mathrm{a}}$ & $(30 \mathrm{nM}) 17.4 \pm 1.7^{\mathrm{a}}$ \\
\hline CAL-27 & $25.0 \pm 1.1$ & $33.3 \pm 2.4$ & $(10 \mathrm{nM}) 31.0 \pm 3.1$ & $14.9 \pm 1.9 \mathrm{a}$ & $(30 n M) 18.8 \pm 2.6$ \\
\hline MCF-7 & $26.2 \pm 1.1$ & $26.4 \pm 1.4$ & $(8 n M) 32.1 \pm 2.0$ & $29.7 \pm 2.2$ & $(20 n M) 32.1 \pm 2.1^{a}$ \\
\hline \multirow[t]{2}{*}{$\mathrm{H} 292$} & $23.4 \pm 0.5$ & $23.5 \pm 1.0$ & $(15 n M) 20.0 \pm 2.8$ & $23.8 \pm 2.3$ & $(40 \mathrm{nM}) 18.2 \pm 1.8^{\mathrm{a}}$ \\
\hline & $\% \mathrm{G} 2 / \mathrm{M}$ & & & & \\
\hline ECV304 & $20.2 \pm 1.0$ & $19.2 \pm 1.0$ & $(10 \mathrm{nM}) 19.6 \pm 2.8$ & $50.2 \pm 1.7 \mathrm{a}$ & $(30 \mathrm{nM}) 62.5 \pm 2.9 \mathrm{a} *$ \\
\hline CAL-27 & $16.1 \pm 0.7$ & $30.4 \pm 3.9^{a}$ & $(10 \mathrm{nM}) 32.8 \pm 5.0^{a}$ & $55.4 \pm 3.3^{a}$ & $(30 \mathrm{nM}) 53.7 \pm 2.4^{\mathrm{a}}$ \\
\hline MCF-7 & $20.3 \pm 0.8$ & $47.2 \pm 6.1^{\mathrm{a}}$ & $(8 n M) 43.9 \pm 1.6^{a}$ & $52.5 \pm 4.7^{a}$ & $(20 \mathrm{nM}) 52.2 \pm 1.2^{\mathrm{a}}$ \\
\hline $\mathrm{H} 292$ & $17.8 \pm 1.0$ & $28.6 \pm 1.3^{\mathrm{a}}$ & $(15 \mathrm{nM}) 50.2 \pm 5.0 \mathrm{a} *$ & $53.2 \pm 6.8^{\mathrm{a}}$ & $(40 \mathrm{nM}) 65.9 \pm 5.0^{\mathrm{a}}$ \\
\hline
\end{tabular}

Percentages of cells in the GI, S and G2/M phase of the cell cycle: after $24 \mathrm{~h}$ incubation with equitoxic concentrations of VRL and VFL; mean \pm standard error.

${ }^{a} \mathrm{p}<0.05$ compared to control

$* \mathrm{p}<0.05$ compared to the equitoxic concentration of VFL

in ECV304 cells, the amount of $\mathrm{S}_{2}$ phase cells was significantly lower after $48 \mathrm{~h}$ incubation with VRL compared to VFL.

Even when VRL or VFL was removed after $24 \mathrm{~h}$ incubation, not all cells could proceed in a normal cell cycle. $24 \mathrm{~h}$ after the VRL or VFL incubation, a polyploid cell cycle was initiated. This was even more pronounced after $48 \mathrm{~h}$ in CAL27 because of the longer doubling time of this cell line.

\section{Discussion}

The strength of this study, thoroughly investigating the radiosensitising and cell cycle effects of both VFL and VRL, is the direct comparison that could be made between the two semisynthetic vinca alkaloids. It is always difficult to compare new results with formerly published results of other research groups, because of the use of other techniques, different experimental set-up, different cell lines, concentrations, etc. Therefore, we used for both VFL and VRL identical experimental conditions and equitoxic concentrations, and performed the experiments in the same four human tumour cell lines. In this manner, the radio-

Table 3: Percentages of cells in the G2/M phase of the cell cycle at different incubation times.

\begin{tabular}{|c|c|c|c|c|c|c|c|}
\hline \multirow[b]{2}{*}{ Cell line } & \multicolumn{7}{|c|}{$\%$ of cells in G2/M } \\
\hline & Control & $4 \mathrm{~h}$ incub. & $6 \mathrm{~h}$ incub. & $16 \mathrm{~h}$ incub. & $20 \mathrm{~h}$ incub. & $24 \mathrm{~h}$ incub. & $48 \mathrm{~h}$ incub. \\
\hline \multicolumn{8}{|c|}{ VRL } \\
\hline ECV304 & $22.5 \pm 1.3$ & $37.7 \pm 1.7^{\mathrm{a}}$ & $45.4 \pm 2.0^{\mathrm{a}}$ & $58.2 \pm 4.3^{\mathrm{a}}$ & $53.9 \pm 6.9^{a}$ & $58.7 \pm 6.5^{\mathrm{a}}$ & $46.4 \pm 6.2$ \\
\hline CAL-27 & $17.9 \pm 1.0$ & $33.3 \pm 1.0^{\mathrm{a}}$ & $40.3 \pm 1.6^{a}$ & $66.9 \pm 5.6^{a}$ & $61.9 \pm 3.9 a$ & $64.3 \pm 4.2^{\mathrm{a}}$ & $23.7 \pm 3.0^{b}$ \\
\hline MCF-7 & $18.1 \pm 1.2$ & $23.2 \pm 1.0^{a}$ & $27.8 \pm 1.5^{\mathrm{a}}$ & $46.3 \pm 3.6 \mathrm{a} *$ & $39.6 \pm 2.0 \mathrm{a} *$ & $42.6 \pm 2.6^{a}$ & $36.6 \pm 2.3^{*}$ \\
\hline $\mathrm{H} 292$ & $18.2 \pm 1.2$ & $31.6 \pm 3.6^{a}$ & $46.8 \pm 5.9 a$ & $71.4 \pm 1.7^{a}$ & $64.8 \pm 4.4^{\mathrm{a}}$ & $64.7 \pm 7.5^{\mathrm{a}}$ & $60.4 \pm 3.1$ \\
\hline \multicolumn{8}{|c|}{ VFL } \\
\hline ECV304 & $20.6 \pm 1.4$ & $32.7 \pm 3.3^{\mathrm{a}}$ & $37.9 \pm 3.1^{\mathrm{a}}$ & $64.1 \pm 5.6^{a}$ & $44.9 \pm 7.3^{\mathrm{a}}$ & $48.7 \pm 6.5^{\mathrm{a}}$ & $42.4 \pm 3.5$ \\
\hline CAL-27 & $17.1 \pm 1.5$ & $33.7 \pm 2.4^{a}$ & $40.9 \pm 1.3^{\mathrm{a}}$ & $61.2 \pm 1.2^{\mathrm{a}}$ & $63.0 \pm 6.5^{\mathrm{a}}$ & $62.7 \pm 5.3^{\mathrm{a}}$ & $21.3 \pm 2.9 b$ \\
\hline MCF-7 & $18.7 \pm 0.9$ & $25.5 \pm 1.8^{a}$ & $30.8 \pm 2.2^{\mathrm{a}}$ & $59.7 \pm 1.0^{a}$ & $54.6 \pm 3.2^{\mathrm{a}}$ & $48.7 \pm 5.9 a$ & $49.3 \pm 2.9$ \\
\hline $\mathrm{H} 292$ & $18.7 \pm 1.1$ & $37.8 \pm 3.2^{\mathrm{a}}$ & $38.5 \pm 4.1^{\mathrm{a}}$ & $65.4 \pm 5.1^{a}$ & $66.0 \pm 4.5^{\mathrm{a}}$ & $69.4 \pm 3.0^{\mathrm{a}}$ & $65.7 \pm 1.8$ \\
\hline
\end{tabular}

Percentages of cells in the G2/M phase of the cell cycle: at different incubation times with VRL and VFL; mean \pm standard error.

${ }^{a} \mathrm{P}<0.05$ compared to control

${ }^{b} \mathrm{p}<0.05$ compared to $24 \mathrm{~h}$ incubation

$* \mathrm{p}<0.05$ compared to the equitoxic VFL concentration 
Table 4: Percentages of cells in the G2/M phase of the cell cycle at different time points.

\begin{tabular}{|c|c|c|c|c|c|c|}
\hline \multirow[b]{2}{*}{ Cell line } & \multicolumn{6}{|c|}{$\%$ of cells in $\mathrm{G} 2 / \mathrm{M}$} \\
\hline & Control & $24+0 \mathrm{~h}$ & $24+3 \mathrm{~h}$ & $24+24 \mathrm{~h}$ & $24+48 \mathrm{~h}$ & $24+72 \mathrm{~h}$ \\
\hline \multicolumn{7}{|c|}{ VRL } \\
\hline ECV304 & $18.1 \pm 0.9$ & $70.3 \pm 2.1^{a}$ & $56.0 \pm 5.8^{b} *$ & $32.6 \pm 1.6^{b}$ & $25.1 \pm 0.8 c$ & $21.4 \pm 1.5^{c}$ \\
\hline CAL-27 & $14.4 \pm 1.2$ & $56.0 \pm 1.1^{\mathrm{a}}$ & $30.7 \pm 3.3^{b}$ & $23.2 \pm 1.3^{b}$ & $21.5 \pm 0.6$ & $24.3 \pm 2.3$ \\
\hline MCF-7 & $17.8 \pm 1.2$ & $53.5 \pm 0.9 a$ & $28.1 \pm 4.4^{b}$ & $35.1 \pm 3.5^{b}$ & $33.1 \pm 0.3$ & $28.6 \pm 3.2$ \\
\hline $\mathrm{H} 292$ & $13.3 \pm 0.8$ & $64.0 \pm 4.2^{\mathrm{a}}$ & $41.9 \pm 1.2^{b}$ & $40.1 \pm 1.5^{b}$ & $37.1 \pm 1.4$ & $27.1 \pm 1.5^{c}$ \\
\hline \multicolumn{7}{|c|}{ VFL } \\
\hline ECV304 & $17.6 \pm 0.9$ & $47.3 \pm 6.9 a$ & $28.2 \pm 2.3^{b}$ & $31.8 \pm 1.7 \mathrm{~b}$ & $27.8 \pm 1.1$ & $23.4 \pm 1.7 c$ \\
\hline CAL-27 & $13.5 \pm 0.5$ & $55.7 \pm 6.6^{\mathrm{a}}$ & $31.8 \pm 3.6 b$ & $24.5 \pm 2.0 \mathrm{~b}$ & $25.0 \pm 0.7$ & $27.6 \pm 1.0$ \\
\hline MCF-7 & $17.2 \pm 1.0$ & $53.3 \pm 5.8^{\mathrm{a}}$ & $36.2 \pm 3.8$ & $27.8 \pm 3.4 \mathrm{~b}$ & $27.3 \pm 3.1$ & $29.8 \pm 3.3$ \\
\hline $\mathrm{H} 292$ & $11.9 \pm 1.4$ & $65.7 \pm 1.1^{\mathrm{a}}$ & $39.5 \pm 1.0^{b}$ & $41.3 \pm 2.3^{b}$ & $41.0 \pm 2.5$ & $26.9 \pm 3.9 c$ \\
\hline
\end{tabular}

Percentages of cells in the G2/M phase of the cell cycle: at different time points after a $24 \mathrm{~h}$ incubation with VRL or VFL; mean \pm standard error. a $\mathrm{p}<0.05$ compared to control

b $\mathrm{p}<0.05$ compared to $24+0 \mathrm{~h}$

${ }^{c} p<0.05$ compared to $24+24 \mathrm{~h}$

$* \mathrm{p}<0.05$ compared to equitoxic VFL conc.

sensitising effect of VFL could be placed in a somewhat more identifiable context.

The radiosensitising effect of both semisynthetic vinca alkaloids was dependent on the cell line tested and most of the time also on the concentration used. When compar- ing the VFL results to those of VRL, only small, statistically insignificant differences were observed. In ECV304 cells, VFL was slightly more radiosensitising than VRL. With a VFL concentration around IC10 the calculated DEF was 1.57 (moderate synergism), while the DEF was 1.49 with the approximately equitoxic VRL (IC15) concentration

Table 5: Percentages of cells in the polyploid cell cycle.

\begin{tabular}{|c|c|c|c|c|c|}
\hline Cell line & Control & $24 \mathrm{~h}$ & $48 \mathrm{~h}$ & $24+24$ & $24+48$ \\
\hline & \multicolumn{5}{|c|}{ Percentage of cells in $\mathrm{S}_{2}$} \\
\hline & VRL & & & & \\
\hline ECV304 & $1.5 \pm 0.2$ & $5.5 \pm 0.9 a$ & $18.5 \pm 1.2^{\mathrm{a} *}$ & $17.6 \pm 2.3^{b}$ & $20.1 \pm 0.9 b$ \\
\hline CAL-27 & $1.3 \pm 0.1$ & $5.6 \pm 1.6$ & $22.9 \pm 1.5^{\mathrm{a}}$ & $12.3 \pm 1.4^{b}$ & $20.2 \pm 0.9 b$ \\
\hline MCF-7 & $2.2 \pm 0.5$ & $2.9 \pm 0.8$ & $9.7 \pm 3.9$ & $4.4 \pm 0.6$ & $8.6 \pm 0.5^{b}$ \\
\hline \multirow[t]{2}{*}{$\mathrm{H} 292$} & $1.4 \pm 0.4$ & $3.0 \pm 1.0$ & $7.9 \pm 1.4^{a}$ & $3.4 \pm 0.7$ & $5.7 \pm 0.9$ \\
\hline & VFL & & & & \\
\hline ECV304 & $1.3 \pm 0.2$ & $7.6 \pm 1.3^{a}$ & $22.4 \pm 0.8^{a}$ & $12.6 \pm 1.1^{b}$ & $16.2 \pm 0.6 \mathrm{~b}$ \\
\hline CAL-27 & $1.7 \pm 0.5$ & $4.3 \pm 1.0$ & $21.8 \pm 1.4^{a}$ & $11.8 \pm 0.7$ & $21.8 \pm 0.8^{b}$ \\
\hline MCF-7 & $2.0 \pm 0.3$ & $2.8 \pm 1.0$ & $8.8 \pm 1.6^{a}$ & $5.2 \pm 0.4$ & $10.6 \pm 1.1^{b}$ \\
\hline \multirow[t]{3}{*}{$\mathrm{H} 292$} & $1.0 \pm 0.2$ & $2.9 \pm 0.5^{a}$ & $7.1 \pm 0.9 \mathrm{a}$ & $3.6 \pm 1.2$ & $4.5 \pm 0.5$ \\
\hline & & & centage of cells & & \\
\hline & VRL & & & & \\
\hline ECV304 & $0.3 \pm 0.0$ & $1.2 \pm 0.2^{\mathrm{a}}$ & $12.2 \pm 1.5^{\mathrm{a}}$ & $9.8 \pm 1.6^{\mathrm{b}}$ & $10.2 \pm 1.3^{b}$ \\
\hline CAL-27 & $0.4 \pm 0.1$ & $2.2 \pm 0.6$ & $37.4 \pm 4.8^{\mathrm{a}}$ & $4.8 \pm 0.5^{b}$ & $6.1 \pm 0.9^{b}$ \\
\hline MCF-7 & $0.5 \pm 0.1$ & $1.3 \pm 0.3$ & $2.1 \pm 0.5$ & $2.1 \pm 0.7$ & $3.4 \pm 0.2^{b}$ \\
\hline $\mathrm{H} 292$ & $\begin{array}{c}0.3 \pm 0.1 \\
\text { VFL }\end{array}$ & $\mathrm{I} . \mathrm{I} \pm 0.3$ & $6.5 \pm 1.0^{\mathrm{a}}$ & $1.4 \pm 0.2$ & $2.2 \pm 0.2^{b}$ \\
\hline ECV304 & $0.2 \pm 0.0$ & $0.8 \pm 0.3$ & $15.6 \pm 0.8^{a}$ & $8.5 \pm 1.3^{b}$ & $9.2 \pm 1.1^{b}$ \\
\hline CAL-27 & $0.3 \pm 0.1$ & $2.1 \pm 0.5$ & $41.8 \pm 4.9 a$ & $5.4 \pm 0.4$ & $7.5 \pm 0.5^{b}$ \\
\hline MCF-7 & $0.5 \pm 0.1$ & $1.3 \pm 0.2^{\mathrm{a}}$ & $4.4 \pm 0.8^{a}$ & $2.0 \pm 0.5$ & $4.4 \pm 0.4^{b}$ \\
\hline $\mathrm{H} 292$ & $0.2 \pm 0.0$ & $1.2 \pm 0.2^{\mathrm{a}}$ & $7.0 \pm 0.9 a$ & $1.9 \pm 0.4$ & $2.4 \pm 0.3^{b}$ \\
\hline
\end{tabular}

Percentages of cells in the polyploid cell cycle: at different incubation times with VRL or VFL and at different times after drug removal; mean \pm standard error.

${ }^{\text {a }} \mathrm{P}<0.05$ compared to control

b $\mathrm{p}<0.05$ compared to $24 \mathrm{~h}$ incubation

$* p<0.05$ compared to equitoxic VFL conc. 
(slight synergism). However, in CAL-27 cells, IC45 concentrations of VRL already caused a more pronounced radiosensitising effect $(\mathrm{DEF}=1.92$, synergistic effect) compared to the equitoxic VFL concentration $(\mathrm{DEF}=1.41$, only an additive effect). MCF-7 was the only cell line in which the radiosensitising effect of VRL was not concentration-dependent, in contrast to the results obtained with VFL.

Regarding the cell cycle effects of VRL, a statistically significant concentration-dependent G2/M block was observed after $24 \mathrm{~h}$ incubation (timepoint of radiation in the chemoradiation experiments). A significant G2/M block was already seen after short incubation times $(4 \mathrm{~h})$, a maximum was reached after $16 \mathrm{~h}$, followed by a significant decrease in the amount of $\mathrm{G} 2 / \mathrm{M}$ phase cells, resulting in recycling of the cells in a normal or polyploid cell cycle. After removal of VRL, cells also started recycling very rapidly (from $3 \mathrm{~h}$ after removal). After $24 \mathrm{~h}$ incubation and especially after a prolonged continuous incubation (48 $\mathrm{h})$, a polyploid population was clearly observed in ECV304 and CAL-27 cells ( $\mathrm{p}$-value $<0.05$ compared to control), and less pronounced in the other cell lines. A similar progress through the cell cycle was observed with VFL treatment, with small (sometimes statistically significant) cell line-dependent differences [30].

Our results obtained with VRL, confirmed and extended the results already described in the literature. Four human tumour cell lines, among which also a bladder and a breast cancer cell line next to a lung and head \& neck cancer cell line, were tested simultaneously. Edelstein et al. investigated 2 human lung carcinoma cell lines (NCI$\mathrm{H} 460$ \& A549) and concluded that $24 \mathrm{~h}$ incubation with VRL before or after radiation resulted in a dose-dependent potentiation of radiation, which was also cell cycledependent, with maximal effect when cells were in the G2 phase of the cell cycle [26]. Also PC9 NSCLC cells were sensitised to radiation by VRL, by causing accumulation of cells in the G2/M phase of the cell cycle. Prolonged G2/M accumulation concomitant with continuous polyploidisation and increased susceptibility to induction of apoptosis may be associated with the cellular mechanism of radiosensitisation produced by VRL in this cell line [27]. As described by Fukuoka et al., SBC-3 cells, human SCLC cells, were also sensitised to radiation by VRL and a possible mechanism of the VRL-induced radiosensitisation may in part, be associated with impairment of DNA repair following radiation-induced DNA damage. It was hypothesized that the disruption of microtubule integrity in SBC3 cells by VRL in part might inhibit p53 transport to the nucleus, resulting in impairment of p53-mediated DNA repair following radiation-induced DNA damage [28]. Erjala et al. investigated the concomitant use of vinorelbine and radiation in 8 head and neck squamous cell car- cinomas (HNSCC). An additive effect (but not supraadditivity) with radiation was noticed in all cell lines tested [29]. The results described in the literature to date, are cell line-dependent and several mechanisms for the radiosensitising effect are proposed.

In view of our results, the observed G2/M block can be related to the radiosensitising effect of VRL after $24 \mathrm{~h}$ incubation followed by radiation. Also the contribution of the polyploid population may be important. In ECV304 and CAL-27, a statistically significant increase in $\mathrm{S}_{2}$ and (G2/ $\mathrm{M})_{2}$ was already observed after $24 \mathrm{~h}$ incubation, although in H292 and MCF-7 this was only the case after a prolonged incubation $(48 \mathrm{~h})$. Further investigation of the polyploid population seems appropriate and of interest. Possible contributions of DNA repair mechanisms or the susceptibility to apoptosis warrants further study.

Overall, our study indicates that the radiosensitising effects of VFL and VRL in vitro are comparable (p-value comparing VRL with VFL never below 0.01), with small, statistically insignificant cell line-related differences, and indeed the cell cycle effects (G2/M block, polyploidisation) can be related to the observed radiosensitising effects. Preclinical studies with VRL have prompted further study of VRL as a radiosensitiser in the clinic. A Phase I study of radiotherapy to the thorax combined with daily VRL (4-6 $\left.\mathrm{mg} / \mathrm{m}^{2}\right)$ administration (as a radiosensitiser) in 14 patients with locally advanced NSCLC resulted in 4 partial responses and 2 complete responses [38]. Also the combined use of VRL with platinum compounds and irradiation has been shown to be feasible. The survival rates achieved with this approach appeared to be superior to those achieved with radiotherapy alone [39]. VFL has not been studied in this setting. However, the advantages of VFL over VRL are the following: (1) it has definite superior antitumour activity against a wide range of experimental tumour models compared to VRL, (2) it proved to be a far less potent inducer of resistance than VRL, (3) it shows a high level of synergy when combined with other chemotherapeutic agents, (4) it has anti-vascular and anti-angiogenic effects at doses below the MTD, (5) it is extremely well tolerated by patients used in a weekly schedule [40]. Combined with a reduced neurotoxicity related to VRL (Table 6), these characteristics make VFL an interesting addition to the currently available armamentarium of chemotherapeutic agents, and, potentially an interesting candidate for chemoradiation studies.

\section{Conclusion}

The radiosensitising effects of VFL and VRL were not statistically different from each other and were nearly always cell line-specific and concentration-dependent. The cell cycle effects could be related to the observed radiosensitising effects. Considering the more favourable toxicity pro- 
Table 6: Comparison between vinflunine and vinorelbine regarding their preclinical effects and their clinical implications.

\begin{tabular}{|c|c|}
\hline \multicolumn{2}{|l|}{ PRECLINICAL STUDIES: } \\
\hline IN VITRO & VFL vs VRL \\
\hline - mechanism of action 3,17 & equal \\
\hline - radiosensitising effect & equal \\
\hline - cell cycle effect & equal \\
\hline - cross-resistance to other MDR-inducing drugs ${ }^{41}$ & VFL: least cross-resistant \\
\hline - inducer of drug resistance ${ }^{15,20}$ & $\begin{array}{l}\text { VFL far less potent than VRL at } 2 \times I C 50 \text { : resistance after } 8 \text { months } \\
\text { instead of within } 2 \text { weeks for VRL }\end{array}$ \\
\hline - combination with other chemotherapeutic agents 42 & VFL: high level of synergy \\
\hline \multicolumn{2}{|l|}{ IN VIVO } \\
\hline \multirow[t]{3}{*}{$\begin{array}{l}\text { - efficacy against a series of murine and human tumour experimental } \\
\text { models } 15,16\end{array}$} & VFL definite superiority to VRL \\
\hline & VFL: high or moderate activity in $64 \%$ (7 of II) \\
\hline & VRL: moderate activity in $27 \%$ ( 3 of 11 ) \\
\hline \multirow[t]{2}{*}{ - inducer of drug resistance 20} & VFL far less readily than VRL \\
\hline & $\begin{array}{l}10 \mathrm{mg} / \mathrm{kg} \text { vs } 2.5 \mathrm{mg} / \mathrm{kg} \text { - P388: complete resistance after } 22 \text { weeks } \\
\text { instead of after } 5 \text { weeks }\end{array}$ \\
\hline - tolerance ${ }^{15,43,44}$ & VFL: high level, superior to VRL \\
\hline - anti-vascular effects ${ }^{44,45}$ & VFL: at doses much lower (5-fold) than the MTD \\
\hline - anti-angiogenic effects 45 & $\begin{array}{l}\text { VFL: at doses below the optimum effective single dose }(40-20 \text {-fold lower } \\
\text { than its MTD) }\end{array}$ \\
\hline - activity against metastases 45 & VFL: significant effects at low doses (16-fold lower than the MTD) \\
\hline \multicolumn{2}{|l|}{ CLINICAL IMPLICATIONS: } \\
\hline - neurotoxicity $5,6,17,18,46$ & VFL: reduced relative to VRL \\
\hline - therapeutic window $6,16,45,47$ & VFL: presumed to be wider than VRL \\
\hline
\end{tabular}

file of VFL, this agent might be more promising than VRL for chemoradiation studies in the clinic.

\section{Competing interests}

F. Breillout is employed by 'Institut de Recherche Pierre Fabre'. All other authors declare that they have no competing interests.

\section{Authors' contributions}

CS participated in the design of the study, performed all the experiments and drafted the manuscript. FL, BP and JBV participated in the conception, design and coordination of the study, and revised the manuscript critically. CDP was involved in the irradiation experiments. HL and GP participated in the cell survival experiments and performed cell culture. FB contributed to the conception of the study and revised the manuscript critically. All authors have read and approved the final manuscript.

\section{Acknowledgements}

This study was financially supported by a grant from the Emmanuel van der Schueren Foundation.

\section{References}

I. Wargin WA, Lucas VS: The clinical pharmacokinetics of vinorelbine (Navelbine). Semin Oncol 1994, 21:21-27.

2. Jordan MA, Thrower D, Wilson L: Mechanism of inhibition by Vinca alkaloids. Cancer Res 1991, 5 1:2212-2222.
3. Wilson L, Panda D, Jordan MA: Modulation of microtubule dynamics by drugs: a paradigm for the actions of cellular regulators. Cell Struct Funct 1999, 24:329-335.

4. Binet S, Chaineau E, Fellous A, Lataste H, Krikorian A, Couzinier JP Meininger V: Immunofluorescence study of the action of navelbine, vincristine and vinblastine on mitotic and axonal microtubules. Int / Cancer 1990, 46:262-266.

5. Ngan VK, Bellman K, Panda D, Hill BT, Jordan MA, Wilson L: Novel actions of the antitumor drugs vinflunine and vinorelbine on microtubules. Cancer Res 2000, 60:5045-505I.

6. Ngan VK, Bellman K, Hill BT, Wilson L, Jordan MA: Mechanism of mitotic block and inhibition of cell proliferation by the semisynthetic vinca alkaloids vinorelbine and its newer derivative vinflunine. Mol Pharmacol 200I, 60:225-232.

7. Okouneva T, Hill BT, Wilson L, Jordan MA: The effects of vinflunine, vinorelbine, and vinblastine on centromere dynamics. Mol Cancer Ther 2003, 2:427-436.

8. Aapro MS, Harper P, Johnson SA, Vermorken JB: Developments in cytotoxic chemotherapy: advances in treatment utilising vinorelbine. Crit Rev Oncol Hematol 200I, 40:25I-263.

9. Depierre A, Lemarie E, Dabouis G, Garnier G, Jacoulet P, Dalphin JC: A phase II study of Navelbine (vinorelbine) in the treatment of non-small-cell lung cancer. Am J Clin Oncol I99I, I 4: I I5-II9.

10. Mano M: Vinorelbine in the management of breast cancer: New perspectives, revived role in the era of targeted therapy. Cancer Treat Rev 2006, 32:106-118.

II. Bennouna J, Breton JL, Tourani JM, Ottensmeier C, O'Brien M, Kosmidis P, Huat TE, Pinel MC, Colin C, Douillard JY: Vinflunine - an active chemotherapy for treatment of advanced non-smallcell lung cancer previously treated with a platinum-based regimen: results of a phase II study. Br J Cancer 2006, 94: $1383-1388$.

12. Bennouna J, Campone M, Delord JP, Pinel MC: Vinflunine: a novel antitubulin agent in solid malignancies. Expert Opin Investig Drugs 2005, 14:1259-1267.

13. Culine S, Theodore C, De Santis M, Bui B, Demkow T, Lorenz J, Rolland F, Delgado FM, Longerey B, James N: A phase II study of vin- 
flunine in bladder cancer patients progressing after first-line platinum-containing regimen. $\mathrm{Br} J$ Cancer 2006, 94:I395-I40I.

14. Kruczynski A, Barret JM, Etievant C, Colpaert F, Fahy J, Hill BT: Antimitotic and tubulin-interacting properties of vinflunine, a novel fluorinated Vinca alkaloid. Biochem Pharmacol 1998, 55:635-648.

15. Kruczynski A, Colpaert F, Tarayre JP, Mouillard P, Fahy J, Hill BT: Preclinical in vivo antitumor activity of vinflunine, a novel fluorinated Vinca alkaloid. Cancer Chemother Pharmacol 1998 4I:437-447.

16. Hill BT, Fiebig HH, Waud WR, Poupon MF, Colpaert F, Kruczynski A: Superior in vivo experimental antitumour activity of vinflunine, relative to vinorelbine in a panel of human tumour xenografts. Eur J Cancer 1999, 35:512-520.

17. Lobert S, Ingram JW, Hill BT, Correia J]: A comparison of thermodynamic parameters for vinorelbine- and vinflunine-induced tubulin self-association by sedimentation velocity. Mol Pharmacol 1998, 53:908-915.

18. Lobert S, Fahy J, Hill BT, Duflos A, Etievant C, Correia J]: Vinca alkaloid-induced tubulin spiral formation correlates with cytotoxicity in the leukemic LI2IO cell line. Biochemistry 2000, 39:12053-12062.

19. Fabre C, Czaplicki J, Wright M, Hill B, Barret JM, Fahy J, Milon A: Differential binding to the alpha/beta-tubulin dimer of vinorelbine and vinflunine revealed by nuclear magnetic resonance analyses. Biochem Pharmacol 2002, 64:733-740.

20. Etievant C, Kruczynski A, Barret JM, Tait AS, Kavallaris M, Hill BT: Markedly diminished drug resistance-inducing properties of vinflunine $\left(20^{\prime}, 20^{\prime}\right.$-difluoro-3',4'-dihydrovinorelbine) relative to vinorelbine, identified in murine and human tumour cells in vivo and in vitro. Cancer Chemother Pharmacol 200I, 48:62-70.

21. Kim TY, Yang SH, Lee SH, Park YS, Im YH, Kang WK, Ha SH, Park Cl, Heo DS, Bang YJ, Kim NK: A phase III randomized trial of combined chemoradiotherapy versus radiotherapy alone in locally advanced non-small-cell lung cancer. Am J Clin Oncol Cancer Clin Trials 2002, 25:238-243.

22. Pignon JP, Bourhis J, Domenge C, Designe L: Chemotherapy added to locoregional treatment for head and neck squamous-cell carcinoma: three meta-analyses of updated individual data. Lancet 2000, 355:949-955.

23. Geh Jl: The use of chemoradiotherapy in oesophageal cancer. Eur J Cancer 2002, 38:300-3I 3.

24. Rose PG: Chemoradiotherapy for cervical cancer. Eur J Cancer 2002, 38:270-278

25. Lukka H, Hirte $\mathrm{H}$, Fyles A, Thomas G, Elit L, Johnston M, Fung MFK, Browman G: Concurrent cisplatin-based chemotherapy plus radiotherapy for cervical cancer - a meta-analysis. Clin Oncol 2002, I 4:203-2I2

26. Edelstein MP, Wolfe LA3, Duch DS: Potentiation of radiation therapy by vinorelbine (Navelbine) in non-small cell lung cancer. Semin Oncol 1996, 23:4I-47.

27. Fukuoka $\mathrm{K}$, Arioka $\mathrm{H}$, Iwamoto $\mathrm{Y}$, Fukumoto $\mathrm{H}$, Kurokawa $\mathrm{H}$, Ishida T, Tomonari A, Suzuki T, Usuda J, Kanzawa F, Saijo N, Nishio K: Mechanism of the radiosensitization induced by vinorelbine in human non-small cell lung cancer cells. Lung Cancer $200 \mathrm{I}$ 34:45I-460.

28. Fukuoka $\mathrm{K}$, Arioka $\mathrm{H}$, Iwamoto $\mathrm{Y}$, Fukumoto $\mathrm{H}$, Kurokawa $\mathrm{H}$, Ishida T, Tomonari A, Suzuki T, Usuda J, Kanzawa F, Kimura H, Saijo N, Nishio K: Mechanism of vinorelbine-induced radiosensitization of human small cell lung cancer cells. Cancer Chemother Pharmacol 2002, 49:385-390.

29. Erjala K, Pulkkinen J, Kulmala J, Grenman R: Concomitant vinorelbine and radiation in head and neck squamous cell carcinoma in vitro. Acta Oncol 2004, 43:169-174.

30. Simoens C, Vermorken JB, Korst AE, Pauwels B, De Pooter CM, Pattyn GG, Lambrechts HA, Breillout F, Lardon F: Cell cycle effects of vinflunine, the most recent promising Vinca alkaloid, and its interaction with radiation, in vitro. Cancer Chemother Pharmacol 2006, 58:210-218

31. Pauwels B, Korst AEC, de Pooter CMJ, Pattyn GGO, Lambrechts HAJ, Baay MFD, Lardon F, Vermorken JB: Comparison of the sulforhodamine B assay and the clonogenic assay for in vitro chemoradiation studies. Cancer Chemother Pharmacol 2003, $5 \mathrm{I}: 22 \mathrm{I}-226$.
32. Papazisis KT, Geromichalos GD, Dimitriadis KA, Kortsaris AH: Optimization of the sulforhodamine B colorimetric assay. J Immunol Methods 1997, 208:15I-I58.

33. Skehan P, Storeng R, Scudiero D, Monks A, McMahon J, Vistica D, Warren JT, Bokesch H, Kenney S, Boyd MR: New colorimetric cytotoxicity assay for anticancer-drug screening. J Natl Cancer Inst 1990, 82: I |07-III

34. Vindelov LL, Christensen IJ, Nissen NI: A detergent-trypsin method for the preparation of nuclei for flow cytometric DNA analysis. Cytometry 1983, 3:323-327.

35. Fertil $B$, Dertinger $H$, Courdi $A$, Malaise EP: Mean inactivation dose: a useful concept for intercomparison of human cell survival curves. Radiation Res 1984, 99:73-84.

36. Chou TC, Talalay P: Quantitative analysis of dose-effect relationships: the combined effects of multiple drugs or enzyme inhibitors. Adv Enzyme Regul 1984, 22:27-55

37. Leonard CE, Chan DC, Chou TC, Kumar R, Bunn PA: Paclitaxel enhances in vitro radiosensitivity of squamous carcinoma cell lines of the head and neck. Cancer Res 1996, 56:5 I98-5204.

38. Gridelli C, Guida C, Barletta E, Gatani T, Fiore F, Barzelloni ML, Rossi A, de Bellis M, D' Aniello R, Scognamiglio F: Thoracic radiotherapy and daily vinorelbine as radiosensitizer in locally advanced non small cell lung cancer: a phase I study. Lung Cancer 2000, 29:131-137.

39. Semrau S, Bier A, Thierbach U, Virchowz C, Ketterer P, Fietkau R: Concurrent radiochemotherapy with vinorelbine plus cisplatin or carboplatin in patients with locally advanced nonsmall-cell lung cancer (NSCLC) and an increased risk of treatment complications. Strahlenther Onkol 2003, I79:823-83I.

40. Delord JP, Stupp R, Pinel M, Nguyen L, Vermorken JB: Phase I study of vinflunine given as a 10 minute intravenous (IV) infusion on a weekly schedule in patients (Pts) with advanced solid tumours. Proc ASCO 200I, 20: (abstr. \# 44I)

4I. Etievant C, Barret JM, Kruczynski A, Perrin D, Hill BT: Vinflunine (20',20'-difluoro-3',4'-dihydrovinorelbine), a novel Vinca alkaloid, which participates in P-glycoprotein (Pgp)-mediated multidrug resistance in vivo and in vitro. Invest New Drugs 1998, 16:3-17.

42. Barret JM, Etievant C, Hill BT: In vitro synergistic effects of vinflunine, a novel fluorinated vinca alkaloid, in combination with other anticancer drugs. Cancer Chemother Pharmacol 2000, 45:47I-476.

43. Bonfil RD, Russo DM, Binda MM, Delgado FM, Vincenti M: Higher antitumor activity of vinflunine than vinorelbine against an orthotopic murine model of transitional cell carcinoma of the bladder. Urol Oncol 2002, 7:159-166.

44. Holwell SE, Hill BT, Bibby MC: Anti-vascular effects of vinflunine in the MAC I5A transplantable adenocarcinoma model. $\mathrm{Br}$ Cancer 200I, 84:290-295.

45. Kruczynski A, Poli M, Dossi R, Chazottes E, Berrichon G, Ricome C, Giavazzi R, Hill BT, Taraboletti G: Anti-angiogenic, vascular-disrupting and anti-metastatic activities of vinflunine, the latest vinca alkaloid in clinical development. Eur J Cancer 2006. doi:10.1016/j.ejca.2006.06.019

46. Kruczynski A, Hill BT: Vinflunine, the latest Vinca alkaloid in clinical development - A review of its preclinical anticancer properties. Crit Rev Oncol Hematol 2001, 40:159-173.

47. Hill BT: Vinflunine, a second generation novel Vinca alkaloid with a distinctive pharmacological profile, now in clinical development and prospects for future mitotic blockers. Curr Pharm Design 2001, 7:1199-1212

\section{Pre-publication history}

The pre-publication history for this paper can be accessed here:

http://www.biomedcentral.com/1471-2407/8/65/prepub 